\title{
FEATURE Tonle Sap Lake and River and confluence with the Mekong River in Cambodia
}

Kenneth R. Olson and Lois Wright Morton

$\mathrm{F}$ or centuries the floating villages on Tonle Sap Lake, Cambodia (figure 1), have derived their livelihoods from the fish and water resources of the lake and its expanding and contracting floodplains. Historically, the lake enabled the powerful Khmer civilization near Siem Reap (figure 2) to develop an elaborate hydraulic complex to irrigate rice (Oryza sativa) fields and support one of the largest premodern urban populations in the world (Goscha 2016). Today the rice-fish diet continues to be the staple of rural and urban daily meals throughout Southeast Asia.

The Tonle Sap River flows 147 km (91 mi) southeast from Tonle Sap Lake to meet during the dry season with the Mekong River near Phnom Penh, the capital of Cambodia. In the monsoon season (May to October), the Mekong River floods and causes the water to back up into the Tonle Sap River, reversing its flow (Carling 2009). This wet season flow reversal brings Mekong River sediments, nutrients, and an abundance of fish into the lake and enlarges the lake into its floodplain 20 to $40 \mathrm{~km}$ (12 to $25 \mathrm{mi}$ ). Farmers and fishers of Cambodia have developed cultural and economic practices based on the Mekong River's dependable dry and wet season patterns and the aquatic species that have adapted to the river pulse and the unique habitats it spawns.

Current and future plans by China, Laos, and Cambodia to build dams for hydroelectricity and floodwater storage on the Mekong River upstream from Phnom Penh are viewed by environmentalists and riparian communities as threats to fisheries, lake and riverbank farming, and local cultures (Olson and Morton 2018; Campbell et al. 2009; Hortle 2009). Small-scale and family farm-

Kenneth R. Olson is professor emeritus of soil science in the Department of Natural Resources and Environmental Sciences, College of Agricultural, Consumer and Environmental Sciences, University of Illinois, Urbana, Illinois, and Lois Wright Morton is professor emeritus of sociology in the Department of Sociology, College of Agriculture and Life Sciences, lowa State University, Ames, lowa.

\section{Figure 1}

The floating villages on the upper $65 \mathrm{~km}$ of Tonle Sap River and in Tonle Sap Lake are home to fisheries: men, women, and children who make their livings catching, processing, and marketing fish, reptiles, frogs and other amphibians, insects, and aquatic vegetation.

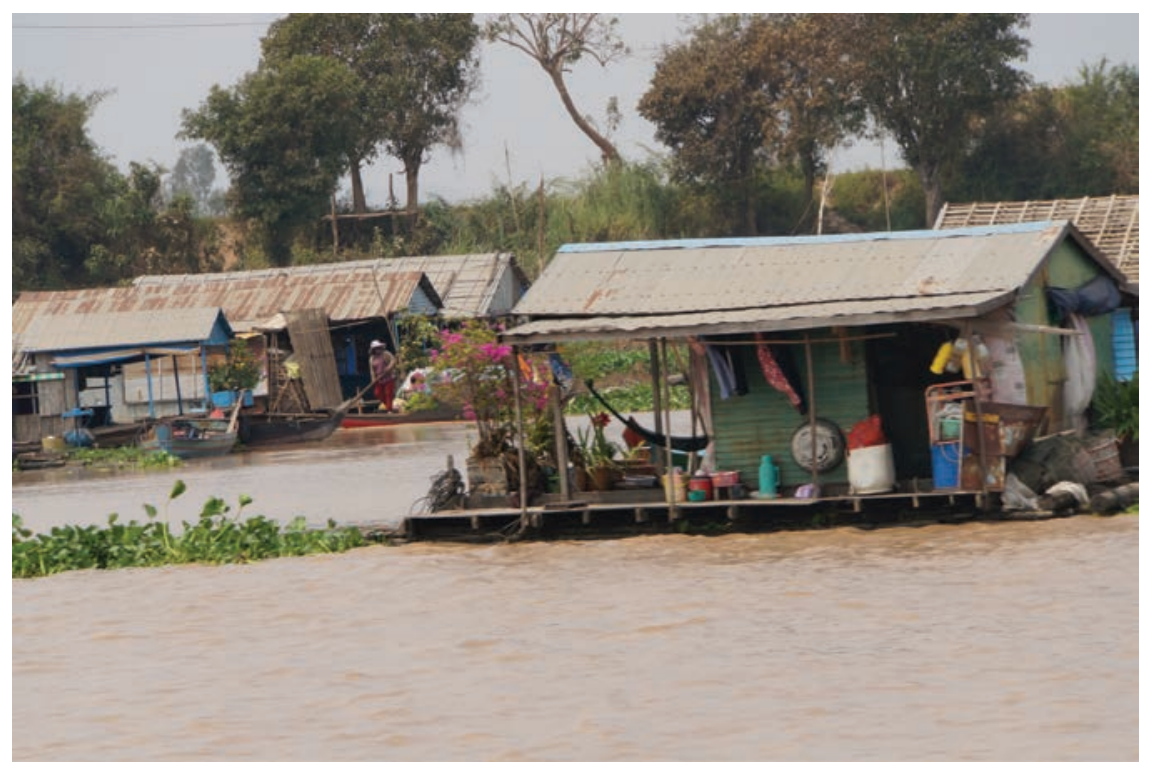

ers produce more than $80 \%$ of Southeast Asia's fish, rice, and vegetables (FAO 2017a) and ensure accessible, affordable high-quality food throughout the region.

Years of civil war in Cambodia (Gosha 2016) have destroyed roads, bridges, and energy infrastructure hindering the country's capacity to modernize. Only 56\% of the Cambodian population has access to electricity, with more than $80 \%$ of the consumption occurring in the urban Phnom Penh area (World Bank 2017). Hydropower is a critical building block for modernization projects in Cambodia, Laos, and Vietnam, and is needed to transform agricultural-based economies into manufacturing, industrial, and servicebased economies that provide jobs and increase family incomes (FAO 2017a). The competing pressures on Cambodia's water resources and the transboundary Mekong River present difficult development and management trade-offs. Lake and riparian communities are untapped sources of local river and lake ecology knowledge that can inform water decisions. Managing the Mekong River and Cambodia's Great Lake to assure food security while building the infrastructure needed to modernize is a social-political-environmental challenge that will need public-private partnerships that include farmers and fishers.

\section{GEOLOGY AND SOILS OF MEKONG RIVER AND TONLE SAP LAKE AND RIVER AREA}

Much of the underlying parent material, hydrologic, and physiographic features of Cambodia are the products of tectonic, erosional, and other geological processes (Carling 2009; Olson and Morton 2018). The Mekong River basin lowlands - the Cambodian plains and the Mekong Delta, are composed primarily of Quaternary and Holocene river alluvium. The Great Lake of Cambodia, Tonle Sap Lake (figure 3), and its alluvial and lacustrine floodplains occupy a geological depression that during the Upper Mesozoic was a wide inland sea. Extending over $44 \%$ of Cambodia's total land area, the Tonle Sap Basin was formed by subsidence as the sea retreated and connected to the 


\section{Figure 2}

The Great Lake of Cambodia (the Tonle Sap Lake) and the Mekong River are valuable water resources for Cambodia in Southeast Asia. Map by Mic Greenberg.

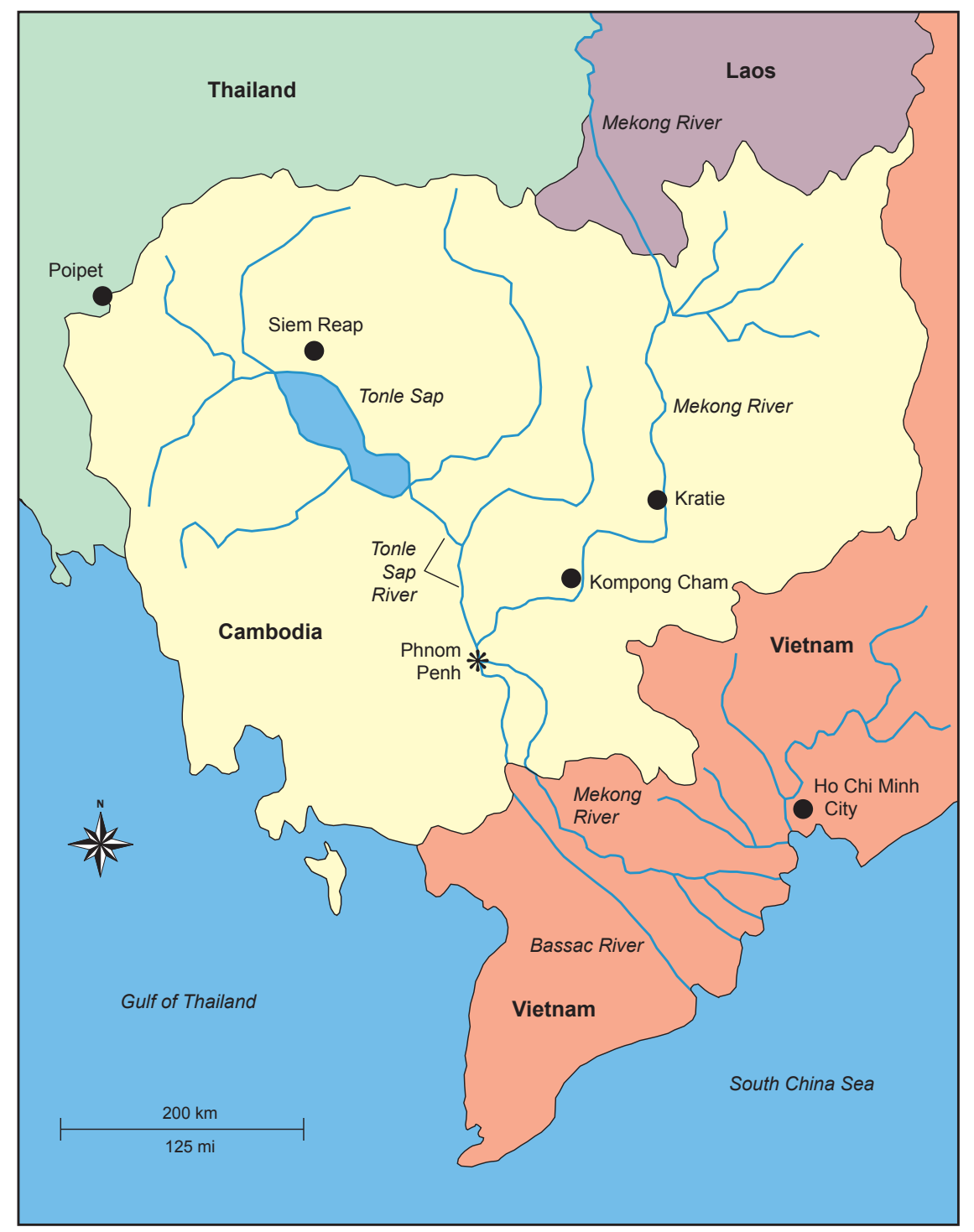

Legend

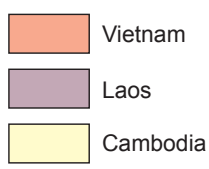

Mekong River system in the last 17,000 years (Carling 2009). The Tonle Sap Lake itself is only about 5,000 to 10,000 years old (Gupta 2009). A bedrock ridge near Kampong Cham prevents the $120 \mathrm{~km}$ (75 mi) long and $35 \mathrm{~km}$ (22 mi) wide permanent lake from fully draining.

Cambodia is entirely within the tropics and has a $443 \mathrm{~km}$ (275 mi) coastline along
Gulf of Thailand (figure 2). The age and general origins of Cambodian soils can be categorized into three distinctly different groupings: (1) regions that retained their original parent material, such as the Cardamom and Central Annamite mountains; (2) regions that are covered by ancient alluvial or colluvial plains; and (3) regions that presently receive annual alluvial sedi- ments, such as the Tonle Sap bottomlands (Greater Mekong Subregion Atlas of the Environment 2012). The central plain includes Tonle Sap Lake and River and the upstream reaches of the Mekong River delta (Campbell et al. 2009). The margins of the low lying central plains are transitional plains consisting of Old Alluvium that rise $200 \mathrm{~m}(656 \mathrm{ft})$ above sea level and are thinly forested. North of these plains from east to west is a sandstone escarpment stretching $320 \mathrm{~km}$ (200 mi).

Sediments deposited on Tonle Sap Lake plain contain marine animal and vegetation materials suggesting the ancient South China Sea once came this far inland. Analyses of soil and geologic cores collected near Angkor Borei, downstream of the current confluence of the Tonle Sap and Mekong rivers, reveal sediments that were deposited in the presence of tides, salt marshes, and mangrove swamps (Sanderson et al. 2006).

Cambodia's soils are predominantly sandy and low in nutrients. The red-soil regions (Oxisols and Ultisols) grow commercial crops, such as cotton (Gossypium herbaceum), tobacco (Niotina tobaccum), rice, and wheat (Triticum aestivum), and perennial tree crops, like rubber (Hevea brasiliensis) and coconut (Cocos nucifera). The Mekong River during the annual wet season carries rich alluvial sediments that are deposited on its floodplains (figure 2 ). These floodwaters improve the central plain soil fertility and provide natural irrigation for rice cultivation. Highlands are forested high plateaus and mountains that rise above the plains. The Kravanh and Damreh mountains form a highland region between Tonle Sap Lake and the Gulf of Thailand.

The Cambodian Mekong floodplain is a large low lying area $800 \mathrm{~km}$ (500 mi) from north to south and $600 \mathrm{~km}(375 \mathrm{mi})$ with an elevation of less than $100 \mathrm{~m} \mathrm{(328}$ $\mathrm{ft}$ ) through which the Mekong River flows on its way to the South China Sea (figure 2). Sediment deposits at Phnom Penh are about $30 \mathrm{~m}(100 \mathrm{ft})$ thick. Upstream, the Mekong River runs northeast from Phnom Penh to Kampong Cham and then turns north to Kratie where bedrock falls block boat traffic on the river during the dry season. 


\section{Figure 3}

The Tonle Sap Lake and River reverse their flow in the monsoon season when the Mekong River floods and backs up into the Tonle Sap River and Lake. With the onset of the dry season, the floodwaters recede, and the Tonle Sap flow changes direction and flows into the Mekong River as it travels southward to the South China Sea. Map by Mic Greenberg.

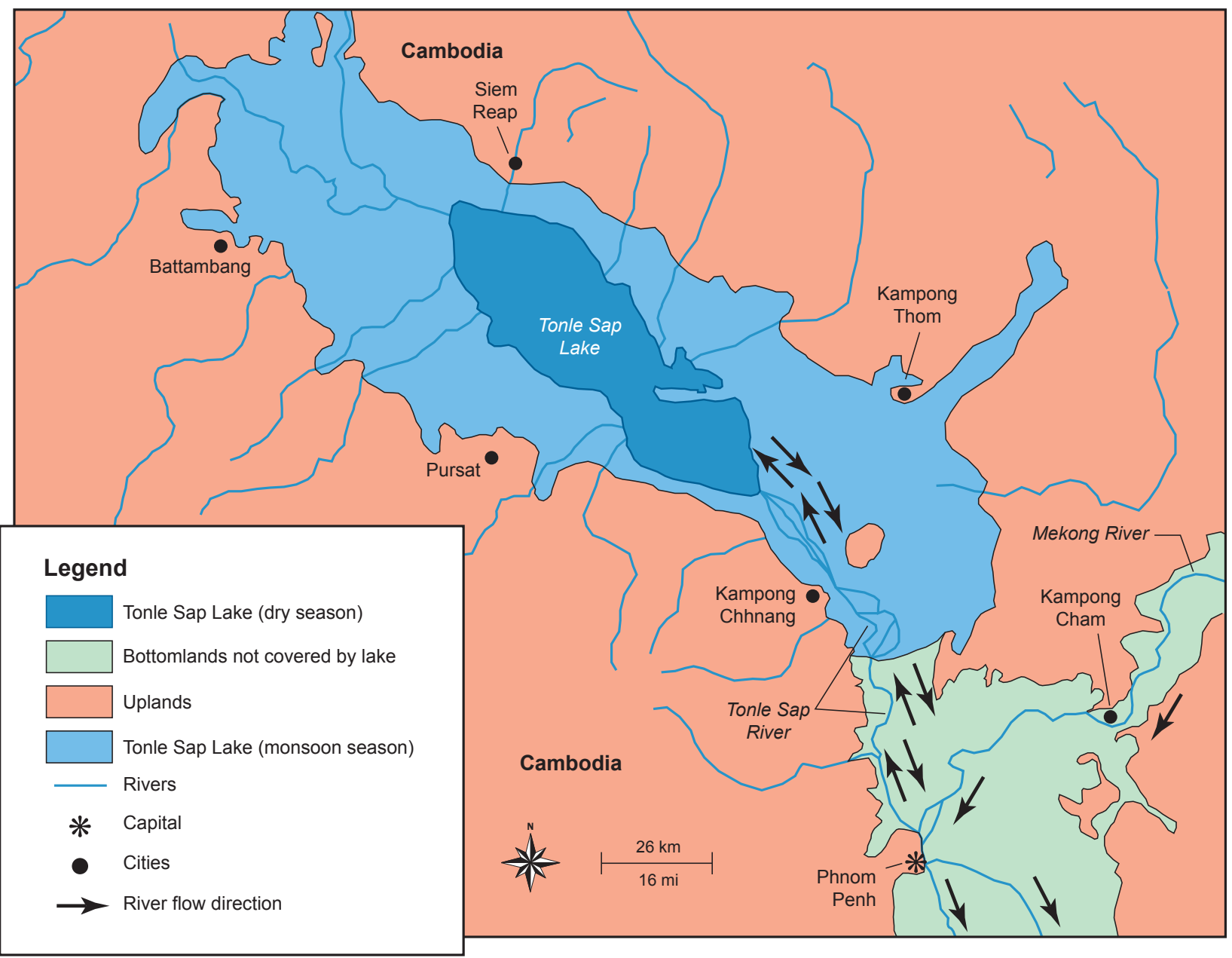

\section{TONLE SAP LAKE AND RIVER}

Tonle Sap Lake and River and the Mekong River dominate the Cambodian landscape. The Mekong River arises out of the Plateau of Tibet and dissects Cambodia on its way to the South China Sea (Olson and Morton 2018). It runs approximately $510 \mathrm{~km}$ (316 mi) through Cambodia from the Khone Falls in Laos to the Vietnam border (figure 2).

Tonle Sap River, a tributary of the Mekong River is $120 \mathrm{~km}$ (74 mi) long during the dry season and connects Tonle Sap Lake to the Mekong near Phnom Penh (figure 3). This unique, complex hydrological system is strongly influenced by the Asian monsoon. A freshwater lake with a rather flat bottom, it is quite shallow during the dry season and seldom exceeds $3.3 \mathrm{~m}(11 \mathrm{ft})$. However, during the wet season, the inundated lake can reach a depth of 8 to $10 \mathrm{~m}$ (26 to $33 \mathrm{ft}$ ).

The Mekong River floods during the rainy season (mid-May to early October), and water backs up into the Tonle Sap River and flows into Tonle Sap Lake (figure 3). Flooding and reverse flows extend the dry season lake $(120 \mathrm{~km}$ long by 35 $\mathrm{km}$ wide [75 by $22 \mathrm{mi}]$ ) into its floodplain and create a wet season lake $250 \mathrm{~km}$ (155 mi) long and $100 \mathrm{~km}$ (62 mi) wide. The dry season Tonle Sap River and Lake surface areas cover $3,100 \mathrm{~km}^{2}\left(1,200 \mathrm{mi}^{2}\right)$ to $7,800 \mathrm{~km}^{2}\left(3,011 \mathrm{mi}^{2}\right)$ and during the wet season expand to cover more than 24,605 $\mathrm{km}^{2}$ (9,500 $\left.\mathrm{mi}^{2}\right)$. Subsequently, the volume of the Tonle Sap Lake expands from 10 $\mathrm{km}^{3}\left(2.4 \mathrm{mi}^{3}\right)$ to $80 \mathrm{~km}^{3}\left(19 \mathrm{~m}^{3}\right)$ during the wet season.

This $200 \%$ to $300 \%$ increase in Tonle Sap Lake's size and $800 \%$ increase in water volume effectively covers the western section of Tonle Sap River and shortens the river length approximately $65 \mathrm{~km}$ (40 mi) during the monsoon season. The lake and river have a natural levee between the permanent lake and surrounding floodplains. Floodplain vegetation has low diversity consisting of rice fields, seasonally inundated forests, and plant communities that are well adapted to the regularity of the flood cycle (Campbell et al. 2009). Homes along the lake and river are either built on stilts or part of floating villages (figure 1) to protect them from seasonal water lev- 
els which can increase the river and lake depths to $10 \mathrm{~m}(33 \mathrm{ft})$.

With the onset of the monsoon season, inflow starts in May/June when the Mekong River begins to flood and back up into the river and lake. Maximum rates of flow peak around $10,000 \mathrm{~m}^{3} \mathrm{~s}^{-1}(360,000$ $\mathrm{ft}^{3} \mathrm{sec}^{-1}$ ) August through October and are amplified by upland runoff and wet season precipitation. In November, the rains stop, and the Mekong River levels begin to drop. Once the Mekong River depth falls below the flooded Tonle Sap and surrounding wetland levels, the river waters reverse their flow and begin draining south again into the Mekong River. Thus, the Tonle Sap River flows northwest for six months a year into the Tonle Sap Lake (figure 3) and then for six months flows in the opposite direction (southeast) into the Mekong River that flows south into the Mekong Delta (figure 2).

As the dry season advances, the river and lake become more and more shallow making navigation on the river and lake increasingly difficult. Only shallow drafting boats enable traffic between Phnom Penh and Siem Reap to continue, and even that would not be possible without the outflow from Tonle Sap Lake. As the water levels drop, the lake turbidity increases when winds kick up the shallow lake and resuspend sediments (Campbell et al. 2009). River and lake nutrient concentrations have similar patterns throughout the course of the year, with both nitrogen $(\mathrm{N})$ and phosphorus (P) peaking in May as water levels increase. This suggests that river water is not diluting or increasing lake nutrient levels.

The water hyacinths during the dry season on the Tonle Sap River reproduce quickly and can wrap on the boat propellers (figure 4) requiring the engines to be reversed periodically to clear the propellers. Boat propellers often hit the soft alluvial sediments and can spray a combination of water and dark sediment into the air behind the speedboat (figure 5), a reminder how shallow Tonle Sap Lake and River become in the dry season. The alluvial sediments and nutrient rich waters of Tonle Sap Lake nurture hundreds of fish species from newly hatched fry to large giant fish (Ferguson et al. 2011). The abun-

\section{Figure 4}

A speedboat plows a path through water hyacinths that grow quickly during the dry season and by March of 2016 covered much of the open waters on the Tonle Sap River.

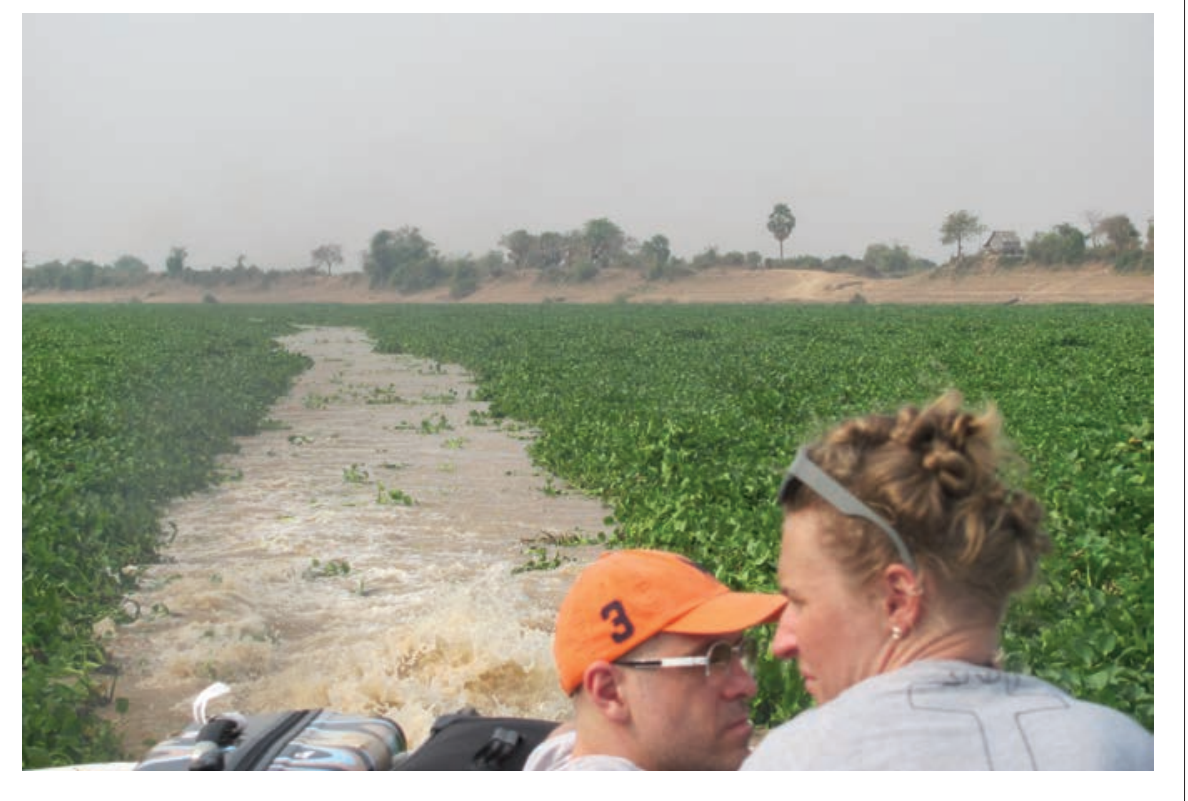

dance of fish and other aquatic species provide food and livelihoods for floating villages (figure 1), communities of houseboats anchored along the edges of Tonle Sap Lake and River.

\section{SEDIMENTATION}

The Mekong River supplies Tonle Sap Lake with water, fish, and sediments via the Tonle Sap River in the monsoon season. Unlike the Mississippi River of the United States, where navigation dominates management decisions and keeping the channel deep is a priority, the Mekong River sediment is highly valued, and its annual transport has made Tonle Sap Lake one of the most highly productive fisheries in the world. The floodwaters bring nutrient-rich sediments into the large, shallow, warm lake and offer ideal conditions for rapid growth of algae (Phaeophyceae) Algae is a key food source in the aquatic ecosystem food web with many of the commercially important fish species in the lake getting their energy from algae growing on attached wet surfaces (Campbell et al. 2009). Flooding also rewets floodplain soils and releases mineralized nutrients to support algae growth as well as providing direct food sources for fish. Larger fish "move into the floodplains and feed on terrestrial vegetation, fruits, detritus," insects, arthropods, and the fry of smaller fish (Hortle 2009).

During the dry season, sediments are resuspended, and the nutrients feed a surge in algae growth, providing food to fish and invertebrates. If the lake depth were permanently at the $10 \mathrm{~m}(33 \mathrm{ft})$ flood season depth, sediment-attached $\mathrm{P}$ and other nutrients would settle to the bottom of the lake, reducing algal access to nutrients. Shallow waters also provide light for fast growth. This internal nutrient cycling is a critical part of the lake and its floodplain productivity.

Much of the sediment in Tonle Sap Lake naturally occurs. However, increased population and rates of development seem to be adding to lake sedimentation through bank erosion and runoff where vegetation has been removed. Local people who live along the banks and floating villages are anecdotally observing some areas of the lake becoming shallower. Research efforts are needed to document sedimentation sources, system rates, and causes of change. Although lake sediments support a thriving fish industry, an increase in river and lake sedimentation has potential to shut down dry season navigation between the capital and regional centers by making the shallow lake even less deep over time. 


\section{Figure 5}

A speedboat carrying passengers from Phnom Penh to Siem Reap, a five-hour trip in the dry season, sits low in the water, and the propeller sprays black sediment and water from the shallow alluvial bottom of Tonle Sap Lake.

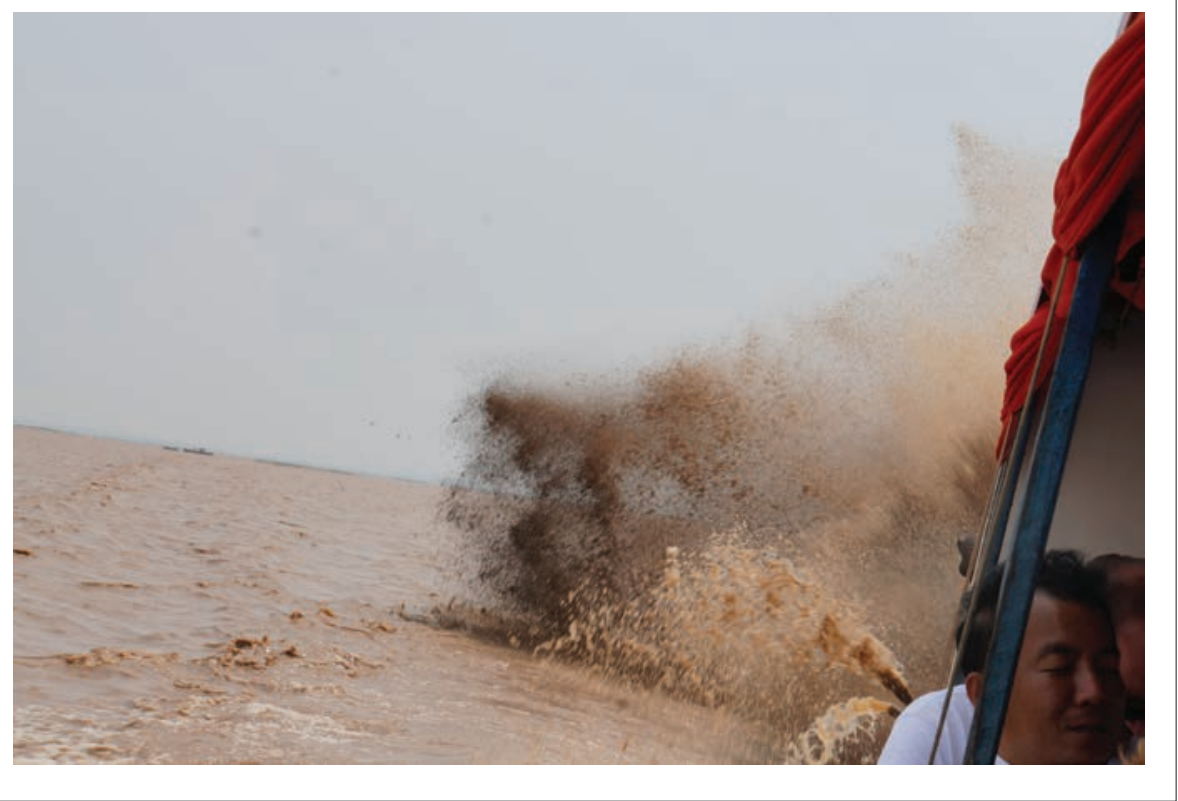

FISHING, AGRICULTURE, AND FORESTRY

Fish are a critical source of protein in the Cambodian diet. Although Cambodian rural people are primarily farmers, almost all of them are also fishers. The word "fisheries" encompasses the entire value chain of lake and river capture fishing and aquaculture production, processing, transporting, and marketing of products (Hortle 2009). Bas-reliefs of ancient Angkor Wat temples near Siem Reap depict fish and fisheries and illustrate the historical significance of the fish culture to food security, wealth, and regional power. Fishers catch a wide variety of species that thrive in water and wetland habitats, including frogs and other amphibians, reptiles, insects, shrimp, crabs, mollusks, and fish.

There is a gendered division of labor, with the men fishing rivers, lakes, and streams as well as rice fields and annually flooded areas. Women make and repair the fishing gear, dry and pickle the fish products, and market them. Although many fisheries are small-scale family efforts to supplement the household income (Ferguson et al.2011), about 40\% of households in Tonle Sap Lake communities are commercial fisheries (Hortle 2009). Two year leases are sold by the government to commercial fishers permitting them to harvest designated areas of the Tonle Sap Lake, the Mekong River, and tributaries.

Almost $85 \%$ of Cambodia's plains and delta regions are planted to rice, making it the largest sector of Cambodian gross domestic product. Paddy rice harvest in 2017 was forecast at 10 million $t$ (11 million tn) with 1.284 million $\mathrm{t}(1.41$ million $\mathrm{tn})$ exported (FAO 2017b). Intensive rice cultivation occurs primarily in Batdambang, Kampong Cham, Takev, and Prey Veng provinces. The more than 3,000 varieties of rice being cultivated have distinct traits that make each uniquely suited to specific soils, water availability, and the seasons: rainy season, dry season (recessional rice), floating, and irrigated rice. Areas that produce rainfed rice have only one crop per year due to lack of water in the dry season needed for double-cropping. Rain-fed rice (80\% of total national production) planting begins with the onset of the rainy season (May to August) with harvest occurring November to January. Rice harvest yields and quality are strongly influenced by timing and amount of rainfall. Localized flooding from too much rain can require replanting or result in crop losses. The characteristics of the rainy season can influence water availability for a secondary planting during the dry season.
The ancient Angkor civilization (ninth to fourteenth century AD) (figure 6) developed complex canals and pond irrigation systems to water inland rice fields as well as bred floating rice on Tonle Sap Lake and other reservoirs to increase rice quality and yields. Much of this innovative technology and infrastructure was lost over years of wars and civil strife. The residue of twentieth century wars are millions of land mines in agricultural fields that severely limit land that can safely be used for rice cultivation (Olson and Morton 2017). The government of Democratic Kampuchea invested in research and irrigation systems to enable farmers to grow two or three rice crops annually. Results were uneven; farmers needed training on using irrigation, and the infrastructure required maintenance and access to water. Many of these irrigation projects were used only a short time and then abandoned after 1979 (Greater Mekong Subregion Atlas of the Environment 2012).

Corn (Zea mays) is the second largest cereal crop grown in Cambodia with $800,000 \mathrm{t}(881,850 \mathrm{tn})$ forecast for harvest in 2017, a 21\% increase from 2016 $(663,000$ t [731,000 tn]) (FAO 2017b). Other Cambodian agricultural crops are sugarcane (Saccharum officinarum), soybean (Glycine max), cassava (Manihot esculenta), and coconuts. Perennial crops such as tropical breadfruits (Artocarpus altilis), mangos (Mangifera indica), papayas (Carica papaya), cashews (Anacardium occidentale), bananas (Musa paradisium), and oranges (Citrus reticulate) are grown and sold in local and regional markets. Saltwater catches and aquaculture fish and shrimp farms are concentrated along the Gulf of Thailand. Water buffalo (Bubalus bubalis) and occasionally cattle (Bos taurus) serve as draft animals to manage rice paddies and other cultivated crops. Ducks (Anas platyrhynchos), chickens (Gallus domesticus), and other poultry and swine (Sus scrofa domesticus) are grown primarily for household consumption and to supplement the family income. Poultry and livestock numbers have been affected by animal diseases and localized violence and wars.

Historically three-quarters of Cambodia was seasonally inundated wetland and upland forests. The combination of government- 
authorized large logging companies and illegal logging has led to high rates of deforestation with forested area reduced by half since the 1970s. The Vietnam War defoliated Cambodian vegetation and jungle forests and left behind unexploded bombs and land mines (Olson and Morton 2017). The bombs and land mines have made land clearing postwar difficult for the Forestry and Agriculture Department, and many Cambodians have unintentionally been killed or maimed. There are still swamps and abandoned rice fields that cannot be safely farmed. It has taken many years of tree planting to restore the vegetation of the jungle forest.

\section{DAMS AND HYDROELECTRIC PLANTS ON THE MEKONG RIVER AND TRIBUTARIES}

The Cambodian energy sector was severely damaged by almost 10 years (1970 to 1979) of civil war. According to the World Bank (2017), about one-third of Cambodia's energy comes from fossil fuels, which are primarily imported. Although the urban centers-Phnom Penh, Siem Reap, Kampong Cham, and Battambang-consume almost $90 \%$ of the total electricity produced, the quality and reliability is consistently poor. Only about $15 \%$ of rural people have electricity, although they make up $85 \%$ of Cambodia's 15.7 million people. The Cambodia Rural Electrification Plan sets a goal of all rural villages having access to electricity produced in different forms by 2020 . Oil, gas, coal, solar, wind, and hydropower have potential but have not been developed.

The Mekong River is a major water resource in Southeast Asia, and all Mekong riparian nations have plans to utilize the river's hydroelectric potential. China and Laos have already built dams and hydroelectric plants on the Mekong main stem and tributaries and are actively planning new dams to produce power in the future (Olson and Morton 2018). The upper Mekong Chinese dams utilize the $810 \mathrm{~m}$ $(2,673 \mathrm{ft})$ drop over a $750 \mathrm{~km}(470 \mathrm{mi}) \mathrm{sec}-$ tion in the middle and lower sections of the Yunnan stretch to produce megawatts of hydropower. Much Lao and Chinese hydroelectricity is exported to neighboring countries and has become an important source of national revenue and regional energy. There are currently plans to build

\section{Figure 6}

Tree roots grow over the Ta Phrohm Temple, part of the elaborate 163 ha religious complex at Angkor Wat (near modern day Siem Reap), built by the Khmer Empire (802 to $1500 \mathrm{AD}$ ).

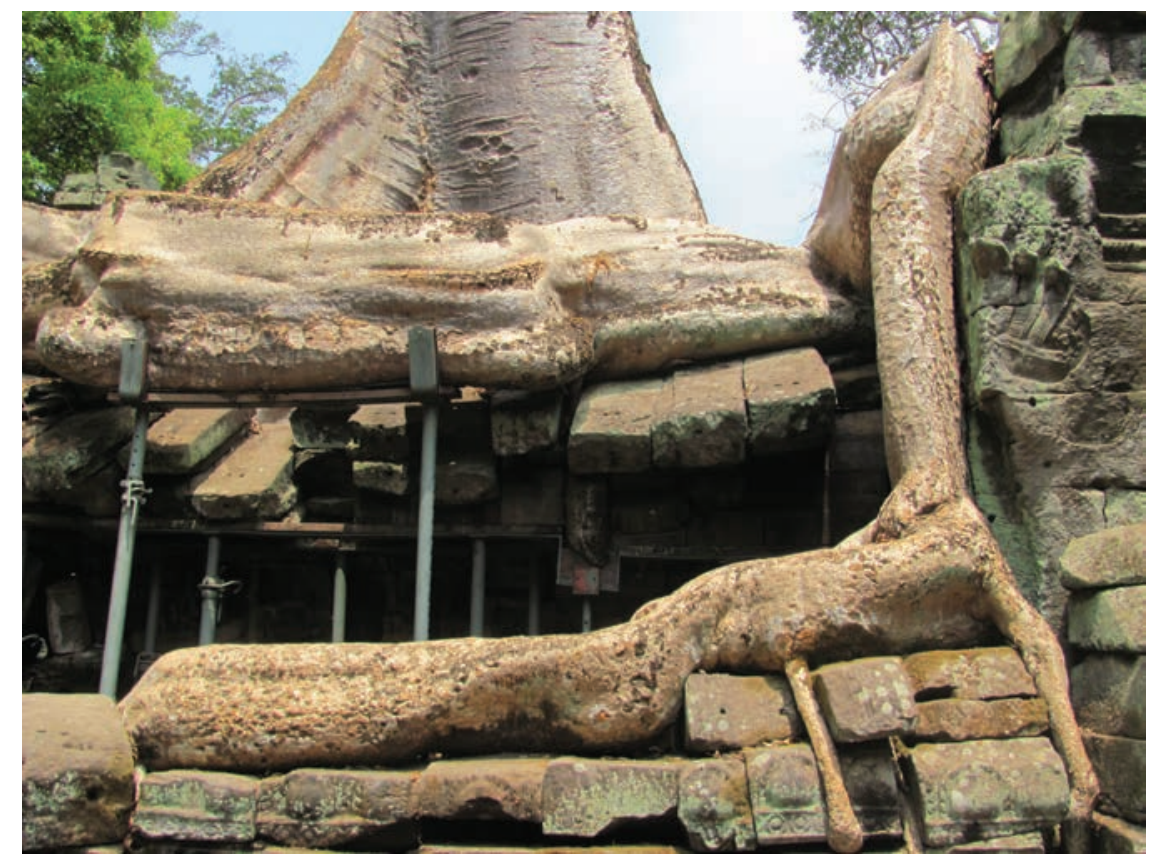

11 reservoirs on the main stem of the lower Mekong River in Laos and Cambodia.

River ecology scientists and environmentalists are concerned about how these dams will affect the hydrological parameters of the Mekong River, tributaries like the Tonle Sap River, and the Great Lake of Cambodia, Tonle Sap Lake. The dams, including the volume and timing of water releases, will alter historically predictable downstream flows and seasonal flood patterns that fish, birds, vegetation, and riparian communities have adapted to over time. Dams could shorten the wet season reverse flows into Tonle Sap Lake and River, regularize dry season lake levels and drainage, and endanger the Tonle Sap eco-region. These changes have implications for breeding, nesting, feeding, and spawning habitats in floodplains and fisheries abundance and diversity.

Fish migration is a large concern when dams block natural river flows. This is especially an issue in a country that is fish dependent for high-quality protein and food security. The sediment- and nutrientfilled waters of Tonle Sap Lake are a natural fish hatchery that self-regulates, and hundreds of fish species annually migrate from the lake to the Mekong River upstream as far north as Laos (Ferguson et al. 2011). It is not known if Xayaburi Dam in Laos, approximately $880 \mathrm{~km}$ (550 mi) upriver, will affect fish migrating from Tonle Sap Lake directly (Olson and Morton 2018). However, a much closer main stem dam, the Don Sahong, being built on the LaoCambodian border will block a known major migration route for dozens of fish species (Ferguson et al. 2011).

A Cambodian dam called Lower Se San 2 is being built $26 \mathrm{~km}$ (16 mi) east of the Se San-Mekong River confluence. This dam will block fish migration between the Se San and the Mekong. Vern Houy village is upstream from the Lower Se San 2 dam site, and homes will be flooded by the reservoir behind the dam (Nijhuis 2015). Villagers are opposed to the dam and have traveled to Phnom Penh as well as written letters to the Cambodian Parliament to explain they do not want to move their village to higher ground and are worried about loss of farming and fishing resources. Their village does not have electricity, although some residents have diesel generators.

Cambodian and Laotian officials claim dams will make electricity less expensive 
and the rural poor will have increased access to power. The Mekong River Commission conducted an analysis in 2010 that predicted fishery losses caused by the dam projects would worsen poverty (Ferguson 2011). Some Cambodian officials counter that aquaculture and rice cultivation can make up for any fish decline in food supplies and incomes, but fishery experts disagree (Campbell et al. 2009). The tradeoffs among hydroelectricity production, food security, and fisheries' livelihoods are difficult and complex. The development of an integrated resource management plan for the Mekong River among the adjacent nine countries is proving no easy task.

\section{CONCLUSIONS}

"Water is a finite and valuable resource essential to sustain life, the environment, and development; it is an economic good which needs managed by broad participatory approaches" (Gunawardena et al. 2012). This statement, known as the 1992 Dublin Principles for water and sustainable development, offers guidance for countries attempting to resolve competing and conflicting national and international uses of water. A central tenet is the call for broad participatory approaches. Managing the Mekong River basin will require national and transnational processes that include local residents in information exchanges and decision making. Riparian communities and floating villages depend on water resources for food security, economic livelihoods, and social and cultural well-being. In many situations, they are losing control of their land, water, and forest resources; are not fully sharing the benefits; and are disproportionately burdened by the social and environmental impacts of dams (Santasombat 2011).

The unique, symbiotic relationship among Tonle Sap Lake and River and the Mekong River is a natural wonder of the world. Concerns about dams blocking annual upstream fish migration, submergence of critical fisheries' breeding habitat, and changes in the flood pulse that supplies nutrients and sediments into Tonle Sap Lake are legitimate and critical issues (Campbell et al. 2009). These are issues that don't just affect Cambodian fishers and farmers, but also impact the food secu- rity of urban people throughout Southeast Asia. There is much not known or understood about the ecological systems of the Mekong River and how they interact with Tonle Sap River and Lake systems. The Mekong River Commission, the voluntary transboundary governance body for the Mekong River; World Bank; countries along the Mekong River; and other international agencies have supported biophysical research over the last few years, but much more is needed to guide good management decisions. Further, biophysical knowledge must be integrated with social science research findings on local knowledge about these ecological systems, perspectives on dam locations and impacts to villages, and adaptive capacities of riparian communities. Local communities have deep knowledge of the river and lake ecosystem and have adapted to the seasonal rhythms of their waters. They can continue to successfully adapt if given opportunity and tools. This is a human resource that can help government and private industries find workable, politically and socially acceptable solutions to the energy crisis Cambodia faces, food security, and the long-term sustainability of Tonle Sap Lake and River ecological systems.

\section{ACKNOWLEDGEMENT}

Published with funding support from the Director of the Illinois Office of Research, College of Agricultural, Consumer, and Environmental Science, University of Illinois, Urbana, Illinois; and the Iowa Agriculture and Home Economics Experiment Station, College of Agriculture and Life Sciences at Iowa State University, Ames, Iowa.

\section{REFERENCES}

Campbell, I.C., S. Say, and J. Beardall. 2009. Tonle Sap Lake, the heart of the Lower Mekong. In The Mekong: Biophysical Environment of an International River Basin, ed. I.C. Campbell, 251-272. New York: Academic Press, Elsevier.

Carling, P.A. 2009. Geomorphology and sedimentology of the lower Mekong River. In The Mekong: Biophysical Environment of an International River Basin, ed. I.C. Campbell, 77-110. New York: Academic Press, Elsevier.

FAO (Food and Agriculture Organization of the United Nations). 2017a. The State of Food and Agriculture. Leveraging Food Systems for Inclusive Rural Transformation. Rome, Italy:
Food and Agriculture Organization of the United Nations. http://www.fao.org/3/a-I7658e.pdf.

FAO. 2017b. GIEWS, Global Information and Early Warning System. Country Briefs. Cambodia (August 4). http://www.fao.org/giews/countrybrief/country.jsp? code $=$ KHM.

Ferguson, J.W., M. Healy, P. Dugan, and C. Barlow. 2011. Potential effects of dams on migratory fish in Mekong River: Lessons from the Frazer and Columbia rivers. Environmental Management 47(1):141-159.

Goscha, C. 2016. Vietnam: A New History. New York: Perseus Books, Basic Books.

Greater Mekong Subregion Atlas of the Environment. 2012. Manila, Philippines: Asian Development Bank.

Gunawardena, E.R.N., B. Gopal, and H. Kotagama. 2012. Ecosystems and Integrated Water Resource Management in South Asia. New York: Routledge.

Gupta,A. 2009. Geology and landforms of the Mekong Basin. In The Mekong: Biophysical Environment of an International River Basin, ed. I.C. Campbell, 29-52. New York:Academic Press, Elsevier.

Hortle, K.G. 2009. Fishers of the Mekong River Basin. In The Mekong: Biophysical Environment of an International River Basin, ed. I.C. Campbell, p. 197-250. New York: Academic Press, Elsevier.

Nijhuis, M. 2015. Harnessing the Mekong or killing it? National Geographic. May 2015. https://www. nationalgeographic.com/magazine/2015/05/ mekong-river-dams/

Olson, K.R., and L.W. Morton. 2017. Why were the soil tunnels of $\mathrm{Cu} \mathrm{Chi}$ and Iron Triangle in Vietnam so resilient? Open Journal of Soil Science 7:34-51, doi.org/10.4236/ ojss.2017.72003. http://file.scirp.org/pdf/ OJSS_2017020911121143.pdf.

Olson, K.R., and L.W. Morton. 2018. Water rights and fights: Lao dams on the Mekong River. Journal of Soil and Water Conservation 73(2):3541A, doi:10.2489/jswc.73.2.35A.

Sanderson, D.C.W., BP. Bishop, M. Stark, S. Alexander and D. Penny. 2006. Luminescence dating of canal sediments form Angkor Borei, Mekong Delta, Southern Cambodia. Quaternary Geochronology 2(1-4):322-329.

Santasombat, Y. 2011. The River of Life: Changing Ecosystems of the Mekong Region. Chiang Mai, Thailand: Mekong Press.

World Bank. 2017. Cambodia. http://data.worldbank.org/indicator. 